\title{
Control of magnetic spin states by various mixed anionic ligands in trinickel complexes: synthesis, crystal structures and physical properties
}

\author{
Ming-Yi Huang, ${ }^{a}$ Chen-Yu Yeh, ${ }^{b}$ Gene-Hsiang Lee ${ }^{a}$ and Shie-Ming Peng*a,c
}

\author{
Received 22nd August 2006, Accepted 18th October 2006 \\ First published as an Advance Article on the web 31st October 2006 \\ DOI: $10.1039 /$ b612123c
}

This study provides an opportunity to control the magnetic spin of nickel atoms using various mixed anionic ligands. A series of linear trinickel complexes supported by two kinds of ligands, oligo- $\alpha$ pyridylamido and sulfonyl amido/amido, were synthesized and their structures were determined by $\mathrm{X}$-ray diffraction. The three nickel atoms of $\left[\mathrm{Ni}_{3}(\mathrm{Lpts})_{2}(\mathrm{dpa})_{2}\right](\mathbf{1})\left(\mathrm{dpa}^{-}=\right.$dipyridylamido, $\mathrm{Lpts}^{2-}=$ $N, N^{\prime}$-bis $(p$-toluenesulfonyl)pyridyldiamido) display short $\mathrm{Ni}-\mathrm{N}(\sim 1.90 \AA)$ bond distances, which are consistent with a low spin state of $\mathrm{Ni}$ (II) ions, and exhibit spin states of $(0,0,0)$ for the three $\mathrm{Ni}(\mathrm{II})$ ions. One of the terminal $\mathrm{Ni}(\mathrm{II})$ ions of $\left[\mathrm{Ni}_{3}(\mathrm{Lms})_{2}(\mathrm{dpa})_{2}\left(\mathrm{H}_{2} \mathrm{O}\right)\right](2)\left(\mathrm{Lms}^{2-}=N, N^{\prime}\right.$-bis(4-methylsulfonyl)pyridyldiamido) and $\left[\mathrm{Ni}_{3}(\mathrm{Lpts})_{2}\left(\right.\right.$ pepteaH $\left.\left.\mathrm{H}_{2}\right)\right](4)\left(\right.$ peptea $\mathrm{H}_{2}{ }^{2-}=$ pentapyridyldiamidodiamine $)$ bonded with an axial ligand exhibits a square pyramidal $\left(\mathrm{NiN}_{4} \mathrm{X}\right)$ geometry with long $\mathrm{Ni}-\mathrm{N}$ bond distances $(\sim 2.10 \AA)$ which are consistent with a high spin Ni(II) configuration. The spin states of these trinickel complexes are $(1,0,0)$. Complex 2 and $\mathbf{6}$ can be interchanged by the removal or addition of an axial water molecule. The structural features of $\mathbf{6}$ are comparable with those of $\mathbf{1}$. Both the terminal $\mathrm{Ni}$ (II) ions in $\left[\mathrm{Ni}_{3}(\mathrm{LAc})_{2}(\mathrm{dpa})_{2}\right](3)\left(\mathrm{Lac}^{2-}=N, N^{\prime}\right.$-biacetyl-pyridyldiamido) are in square pyramidal geometry and exhibit high spin. The spin states of the nickel ions in $\mathbf{3}$ are $(1,0,1)$, and the two terminal nickel ions exhibit antiferromagnetic interactions. The molecular structure of $\left[\mathrm{Ni}_{3}(\mathrm{Lpts})_{2}(\mathrm{dpa})_{2}\right]\left(\mathrm{BF}_{4}\right)(\mathbf{5})$, which was obtained by the one-electron oxidation of $\mathbf{1}$, is similar to those of the neutral analogue $\mathbf{1}$, except for the presence of a counter anion to compensate for the positive charge on the $\mathrm{Ni}_{3}$ core. All of the Ni-Ni bond lengths of $\mathbf{5}$ are slightly shorter $(c a .0 .05 \AA)$ than those in the neutral analogues. This is attributed to the formation of partial $\mathrm{Ni}-\mathrm{Ni}$ bonding.

\section{Introduction}

The study of metal-metal interactions in transition metal complexes has been an interesting and important subject in inorganic chemistry. ${ }^{1}$ In the past decade, the study of metal-metal interactions has focused on the extension of dinuclear metal complexes ${ }^{2-4}$ to metal string complexes supported by oligo- $\alpha$-pyridylamido ligands such as $\left[\mathrm{M}_{3}(\mathrm{dpa})_{4} \mathrm{X}_{2}\right](\mathrm{M}=\mathrm{Cr}, \mathrm{Co}, \mathrm{Ni}, \mathrm{Cu}, \mathrm{Rh}, \mathrm{Ru}){ }^{5-10}$ $\left[\mathrm{M}_{5}(\mathrm{tpda})_{4} \mathrm{X}_{2}\right]\left(\mathrm{M}=\mathrm{Cr}, \mathrm{Co}, \mathrm{Ni}\right.$; tpda ${ }^{2-}=$ tripyridyldiamido $),{ }^{11-13}$ $\left[\mathrm{M}_{7}(\text { teptra })_{4} \mathrm{X}_{2}\right]\left(\mathrm{M}=\mathrm{Cr}, \mathrm{Ni}\right.$; teptra ${ }^{3-}={\text { tetrapyridyltriamido })^{14-15}}^{15}$ and $\left[\mathrm{M}_{9}\right.$ (peptea) $\left.{ }_{4} \mathrm{X}_{2}\right](\mathrm{M}=\mathrm{Ni}) \cdot{ }^{16}$ Recently, we have been interested in exploring the coordination chemistry of multidentate ligands other than oligopyridylamines such as $\mathrm{LptsH}_{2}$ and $\mathrm{LAcH}_{2}$. The unique feature of these ligands is that they are tridentate and dianionic when depronated. In this paper, we describe a new type of metal string complex in which the trimetal core is supported by two kinds of oligo- $\alpha$-pyridylamido and sulfonyl amido/amido ligands and exhibits different magnetic spin states.

For clarity, the trinickel complexes presented in this paper are as follows: $\left[\mathrm{Ni}_{3}(\mathrm{Lpts})_{2}(\mathrm{dpa})_{2}\right](\mathbf{1}),\left[\mathrm{Ni}_{3}(\mathrm{Lms})_{2}(\mathrm{dpa})_{2}\left(\mathrm{H}_{2} \mathrm{O}\right)\right]$ (2), $\left[\mathrm{Ni}_{3}(\mathrm{LAc})_{2}(\mathrm{dpa})_{2}\right](3),\left[\mathrm{Ni}_{3}(\mathrm{Lpts})_{2}\left(\right.\right.$ pepteaH $\left.\left.\mathrm{H}_{2}\right)\right](4),\left[\mathrm{Ni}_{3}(\mathrm{Lpts})_{2}-\right.$ $\left.(\mathrm{dpa})_{2}\right]\left(\mathrm{BF}_{4}\right)(\mathbf{5}),\left[\mathrm{Ni}_{3}(\mathrm{Lms})_{2}(\mathrm{dpa})_{2}\right](\mathbf{6})$.

${ }^{a}$ Department of Chemistry, National Taiwan University, Taipei, Taiwan ${ }^{b}$ Department of Chemistry, National Chung Hsing University, Taichung, Taiwan

'Institute of Chemistry, Academia Sinica, Taipei, Taiwan.E-mail:smpeng@, ntu.edu.tw

\section{Results and discussion}

\section{Synthesis and structures}

The synthetic procedures for compounds $\mathbf{1} \mathbf{- 6}$ are summarized in Scheme 1. Compounds $\mathbf{1 - 4}$ are synthesized by the reaction of $\mathrm{Ni}(\mathrm{OAc})_{2} \cdot 4 \mathrm{H}_{2} \mathrm{O}$ with the appropriate ligands using naphthalene as the solvent. In our previous reports on multinuclear metal string complexes, ${ }^{7,9,11-13}$ the preparation of these complexes involved the use of an additional base for the deprotonation of the ligands. In the modified procedure using $\mathrm{Ni}(\mathrm{OAc})_{2} \cdot 4 \mathrm{H}_{2} \mathrm{O}$ instead of $\mathrm{NiCl}_{2}$, it is not necessary to use an additional base for deprotonation since it can be accomplished by the $\mathrm{OAc}^{-}$anion. The one-electron oxidized product $\left[\mathrm{Ni}_{3}(\mathrm{Lpts})_{2}(\mathrm{dpa})_{2}\right]\left(\mathrm{BF}_{4}\right)$ (5) was obtained by reacting the neutral complexes with nitrosyl tetrafluoroborate, the redox potential of which is more anodic than the formal potential for the first oxidation of the neutral complex. Compound $\mathbf{6}$ can be obtained by putting 2 under vaccum at $120^{\circ} \mathrm{C}$ for $48 \mathrm{~h}$. Summaries of the structural data for compounds $\mathbf{1 - 6}$ are given in Table 1. Table 2 gives some selected bond distances for compounds 1-6. The structure of compound $\mathbf{1}$ is depicted in Fig. 1. The trinickel core is linear and supported by two $\mathrm{Lpts}^{2-}$ and two dpa ligands, in which the same ligands are trans to each other. Each of the three $\mathrm{Ni}$ (II) ions are coordinated by four nitrogen atoms with a square planar arrangement. All the $\mathrm{Ni}-\mathrm{N}$ distances lie in the range of 1.89-1.95 $\AA$, which indicates that the nickel ions are in a low spin state. In this class of multinuclear metal complexes, examples of compounds without axial ligands are rare. 


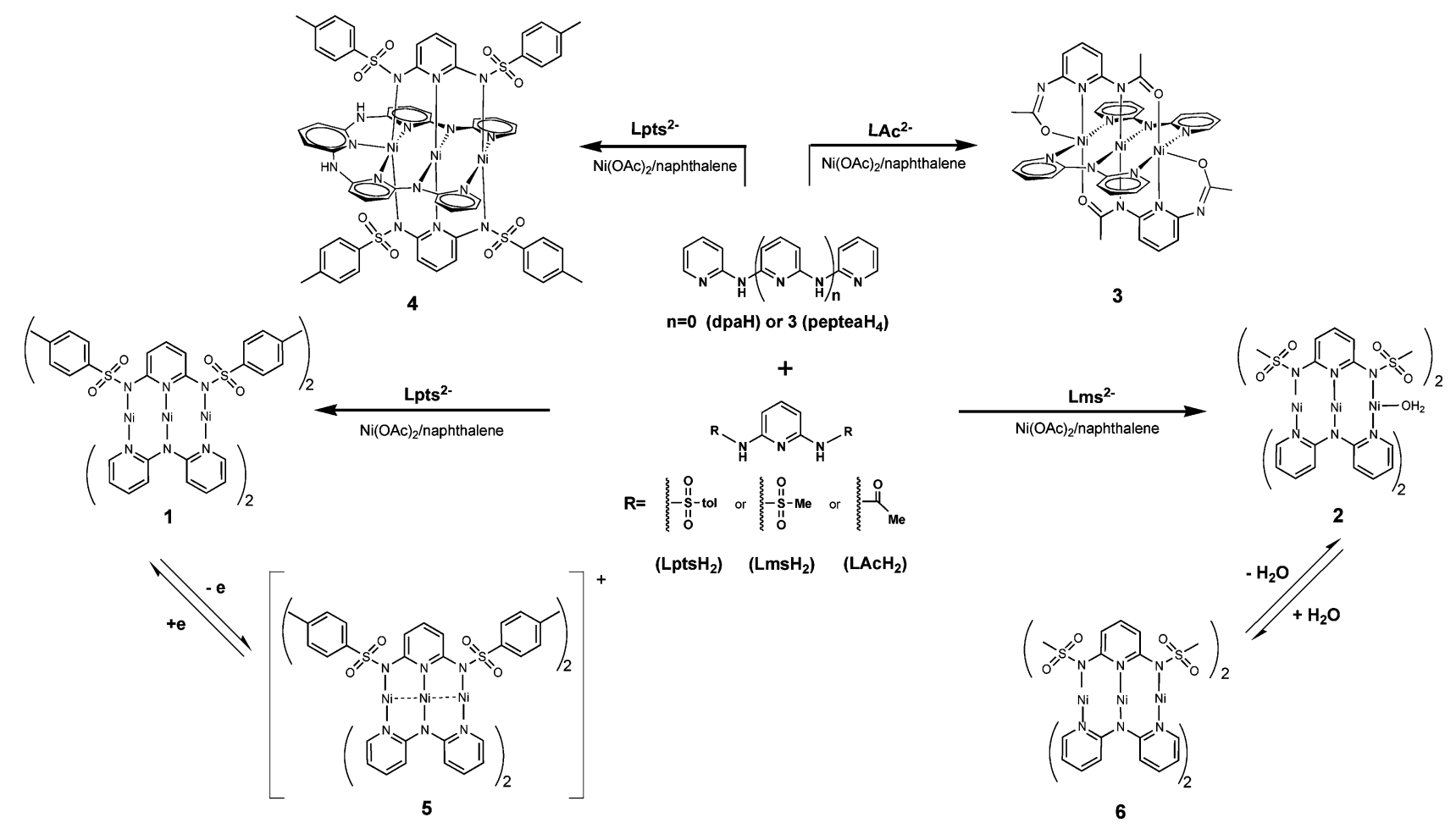

Scheme 1 General route for the preparation of linear trinuclear nickel string mixed ligand complexes.

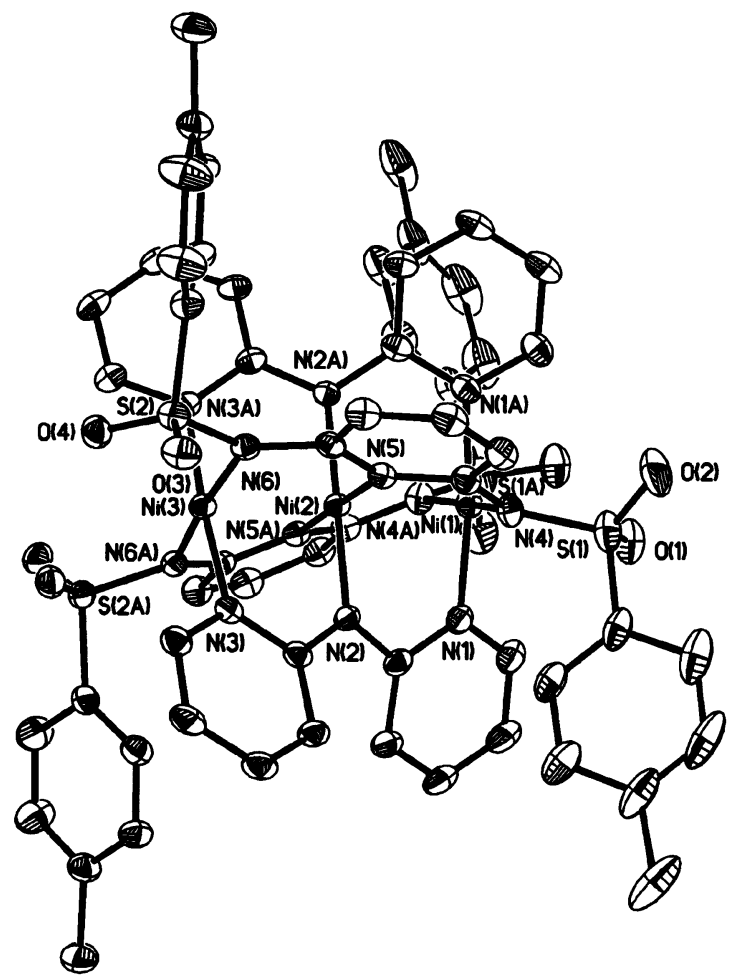

Fig. 1 Crystal structure of $\mathbf{1}$. Thermal ellipsoids are drawn at the $30 \%$ probability level. Hydrogen atoms are omitted for clarity.

In 1999, we reported the structure of a tetranickel complex 7. ${ }^{17}$ Soon after the publication of our report, another trinickel complex 8 without axial ligands was synthesized (Scheme 2). ${ }^{18}$ In comparison with $\mathbf{7}$ and $\mathbf{8}$, the Ni-Ni bond distances of 2.3573(8) and 2.3516(8) $\AA$ in compound $\mathbf{1}$ are longer than those in $\mathbf{7}$ (2.3269(6), 2.3010(6) and 2.3280(6) $\AA$ ) and slightly shorter than those in $8(2.368(1) \AA)$. The Ni-N bond distances in these three compounds are comparable, all being in the range of 1.89-1.95 $\AA$, which are consistent with a low spin state of $\mathrm{Ni}(\mathrm{II})$. The two $\mathrm{C}(\mathrm{Py})-\mathrm{N}$ (amido) bond distances are 1.377(4) and 1.391(4) $\AA$ in compound $\mathbf{1}$, which are longer than those in $8(1.358 \AA){ }^{18}$ This means that the negative charge is more localized at the N(amido) in compound $\mathbf{1}$ than in $\mathbf{8}$, because toluenesufonyl (Ts) is a stronger electron withdrawing group than phenyl. López et al. have shown that substitution of phenyls with toluenesulfonyls in $\mathbf{8}$ results in a spin state change from diamagnetic to quintet ground state. ${ }^{19}$

Fig. 2 and 3 show the crystal structures of compounds 2 and 4. It is noted that the identity of the axial ligands could influence the $\mathrm{Ni}-\mathrm{Ni}$ and $\mathrm{Ni}-\mathrm{N}$ bond distances. In compounds $\mathbf{2}$ and $\mathbf{4}$, one of the terminal nickel ions is five-coordinate and the $\mathrm{Ni}-\mathrm{N}$ bond distances ( $c a .2 .10 \AA$ ) and Ni-Ni bond distances ( $c a .2 .39 \AA$ ) are longer than those of the other terminal nickel ion without axial ligands. This indicates that the five-coordinate nickel ion is in a high spin state. Both structures have trans geometry.

The crystal structure of compound $\mathbf{3}$ is shown in Fig. 4. The linear trinickel core is helically wrapped by two $\mathrm{dpa}^{-}$and two $\mathrm{LAc}^{2-}$ ligands with cis configuration. The two terminal nickel ions are five-coordinate. Interestingly, one of the nitrogen atoms of the $\mathrm{LAc}^{2-}$ ligands is not involved in coordination to the nickel ions and the axial ligands are provided by one of the oxygen atoms of the $\mathrm{LAc}^{2-}$ ligands. The central nickel atom is square planar with four short $\mathrm{Ni}-\mathrm{N}$ bond distances in the range of 1.86-1.90 $\AA$, which are consistent with a low spin $(S=0)$ square planar Ni(II) ion. Both the terminal $\mathrm{Ni}$ (II) atoms are in a square pyramidal environment with long Ni-N distances in the range of 2.05-2.11 $\AA$. This is consistent with a high $\operatorname{spin}(S=1) \mathrm{Ni}(\mathrm{II})$ configuration. 


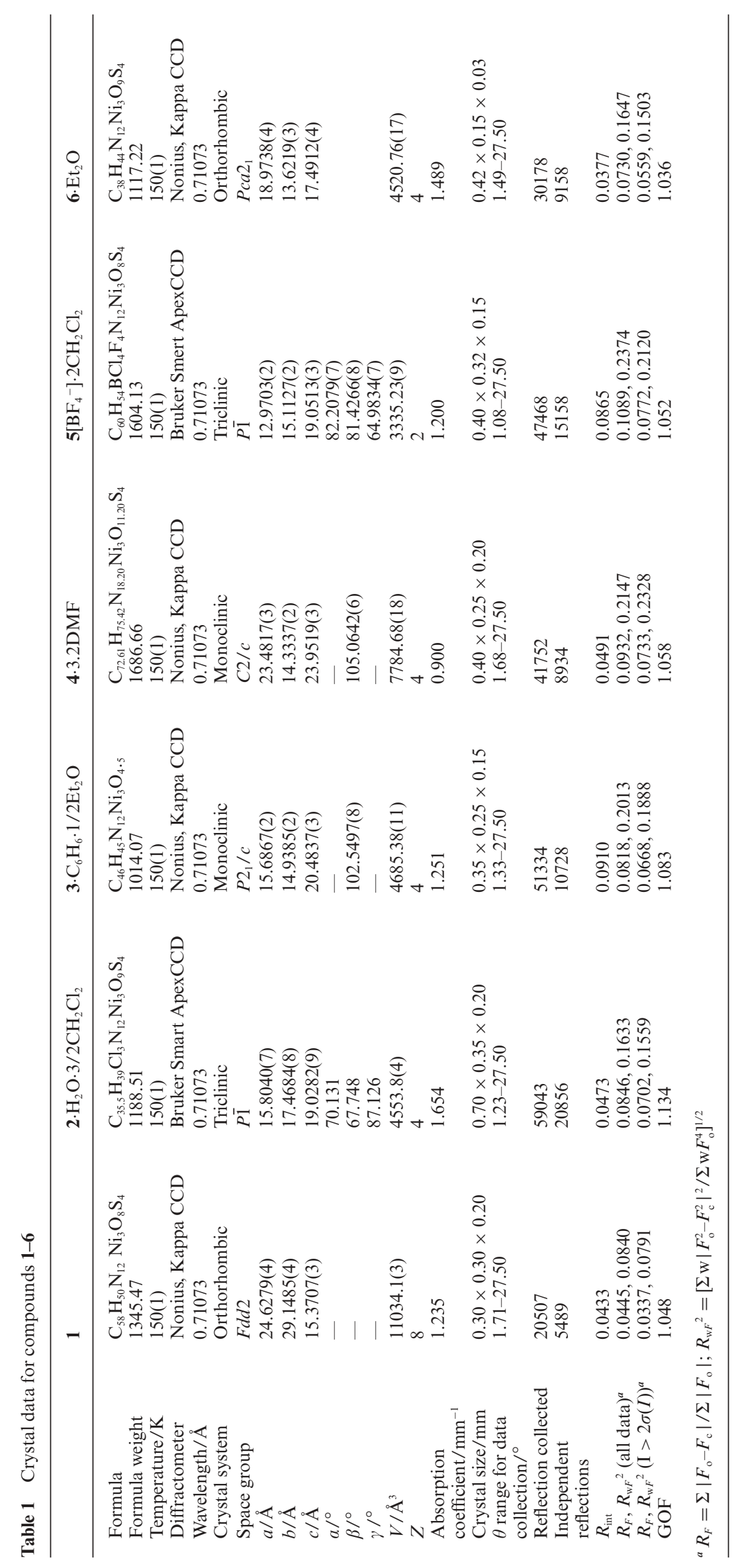


Table 2 Selected bond distances ( $\AA$ ) for compounds 1-6

\begin{tabular}{|c|c|c|c|c|c|c|}
\hline & 1 & 2 & 3 & 4 & 5 & 6 \\
\hline $\mathrm{Ni}(1)-\mathrm{Ni}(2)$ & $2.3573(8)$ & $2.3484(8)$ & $2.4055(6)$ & $2.3581(10)$ & $2.3086(8)$ & $2.3464(11)$ \\
\hline $\mathrm{Ni}(2)-\mathrm{Ni}(3)$ & $2.3516(8)$ & $2.3881(8)$ & $2.4015(6)$ & $2.3908(9)$ & $2.3047(7)$ & $2.3611(11)$ \\
\hline $\mathrm{Ni}(1)-\mathrm{O}_{\mathrm{e}}$ & - & - & $2.074(3)$ & - & - & - \\
\hline $\mathrm{Ni}(2)-\mathrm{N}_{\mathrm{eq}}$ & $1.921(2)$ & $1.914(4)$ & $1.895(3)$ & $1.915(3)$ & $1.901(4)$ & $1.914(5)$ \\
\hline $\mathrm{Ni}(3)-\mathrm{N}_{\mathrm{eq}}$ & $1.927(2)$ & $2.081(4)$ & $2.059(3)$ & $2.073(3)$ & $1.909(4)$ & $1.934(7)$ \\
\hline $\mathrm{Ni}(3)-\mathrm{O}_{\mathrm{eq}}$ & - & - & $2.071(3)$ & - & - & - \\
\hline
\end{tabular}

$\mathrm{Y}$ is the axial ligand, eq $=$ equatorial.

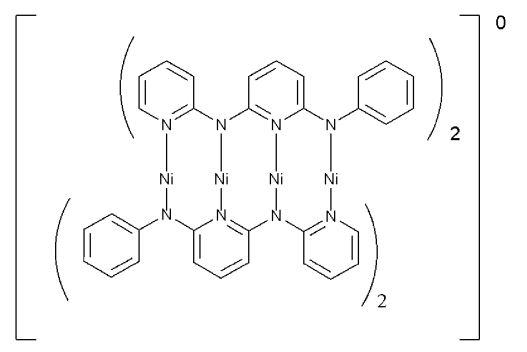

7

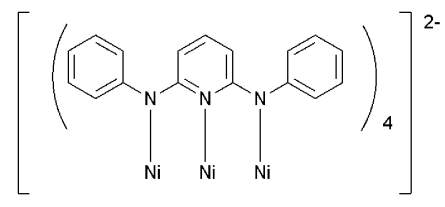

8

Scheme 2

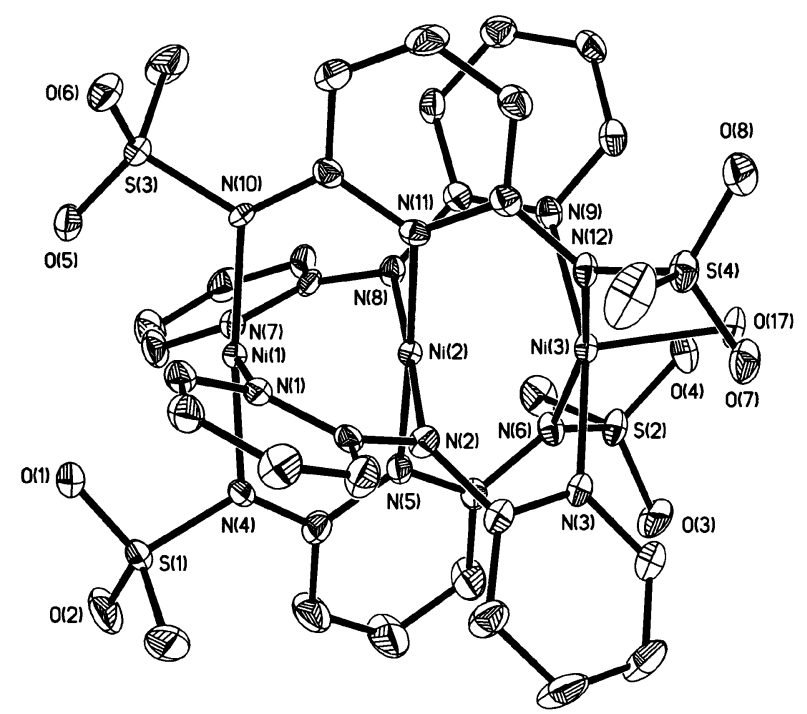

Fig. 2 Crystal structure of 2. Thermal ellipsoids are drawn at the $50 \%$ probability level. Hydrogen atoms are omitted for clarity.

As shown in Fig. 5, the molecular structure of the one-electron oxidized compound $\mathbf{5}$ is similar to that of the neutral analogue 1, except for the presence of a counter anion to compensate for the positive charge on the $\mathrm{Ni}_{3}$ core. We expected that some of the interatomic bond distances would be shorter compared to those in the neutral compounds. However, the Ni-N distances for all the nickel atoms were only slightly changed upon oneelectron oxidation. Moreover, all the $\mathrm{Ni}-\mathrm{Ni}$ bond lengths are slightly shorter ( $c a .0 .05 \AA$ ) than those in the neutral analogues due to the formation of partial $\mathrm{Ni}-\mathrm{Ni}$ bonds.

The crystal structure of compound $\mathbf{6}$ is shown in Fig. 6. Because compound $\mathbf{6}$ has no axial ligation, the structural and magnetic

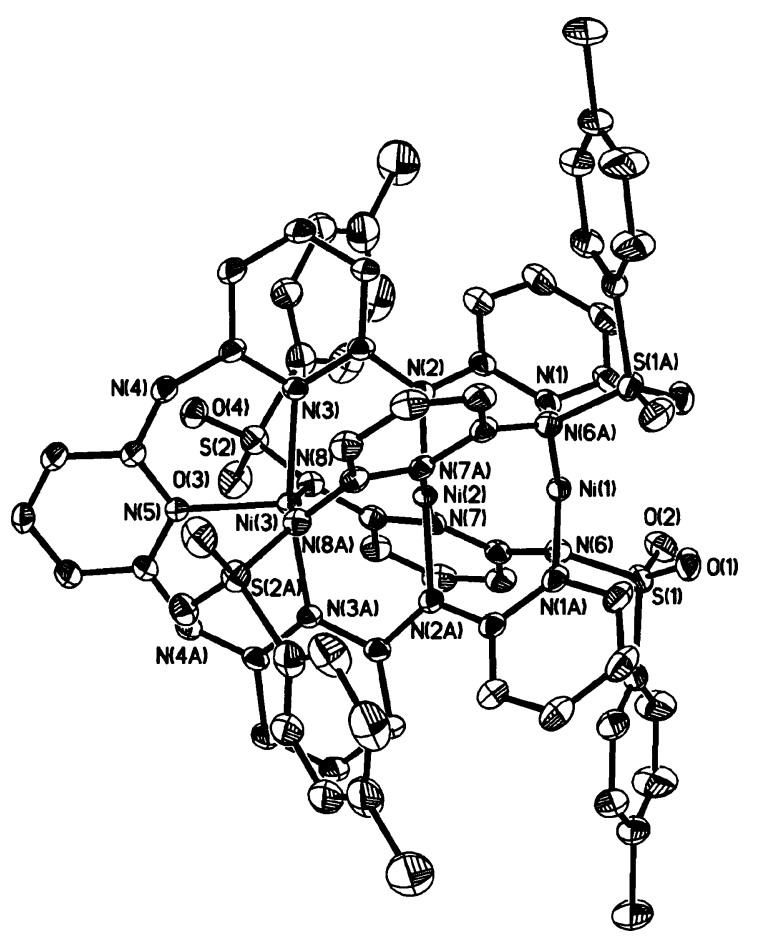

Fig. 3 Crystal structure of 4 . Thermal ellipsoids are drawn at the $30 \%$ probability level. Hydrogen atoms are omitted for clarity.

characterizations of compound $\mathbf{6}$ are different from those of compound $\mathbf{2}$ and identical to those of compound $\mathbf{1}$. The trinickel core is linear and supported by two $\mathrm{Lms}^{2-}$ and two dpa- ligands, in which the same ligands are trans to each other. Each of the three $\mathrm{Ni}(\mathrm{II})$ ions are coordinated by four nitrogen atoms with a square planar arrangement. All the $\mathrm{Ni}-\mathrm{N}$ distances lie in the range of $1.89-1.95 \AA$. 


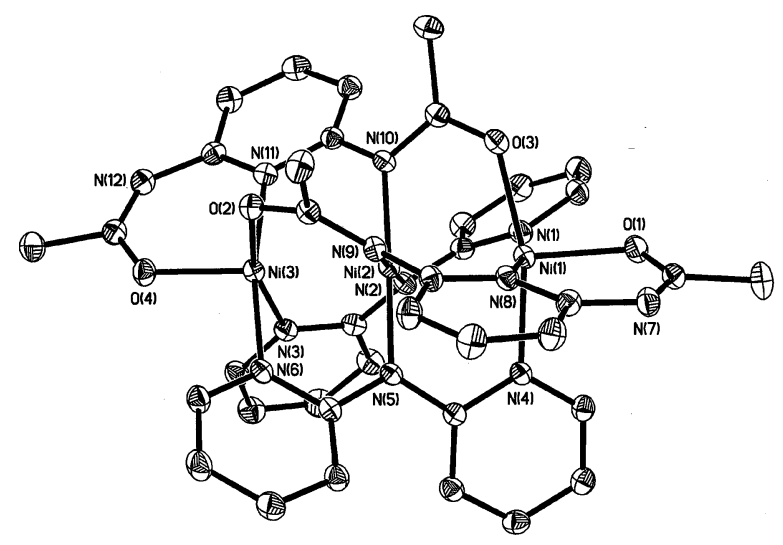

Fig. 4 Crystal structure of 3. Thermal ellipsoids are drawn at the 30\% probability level. Hydrogen atoms are omitted for clarity.

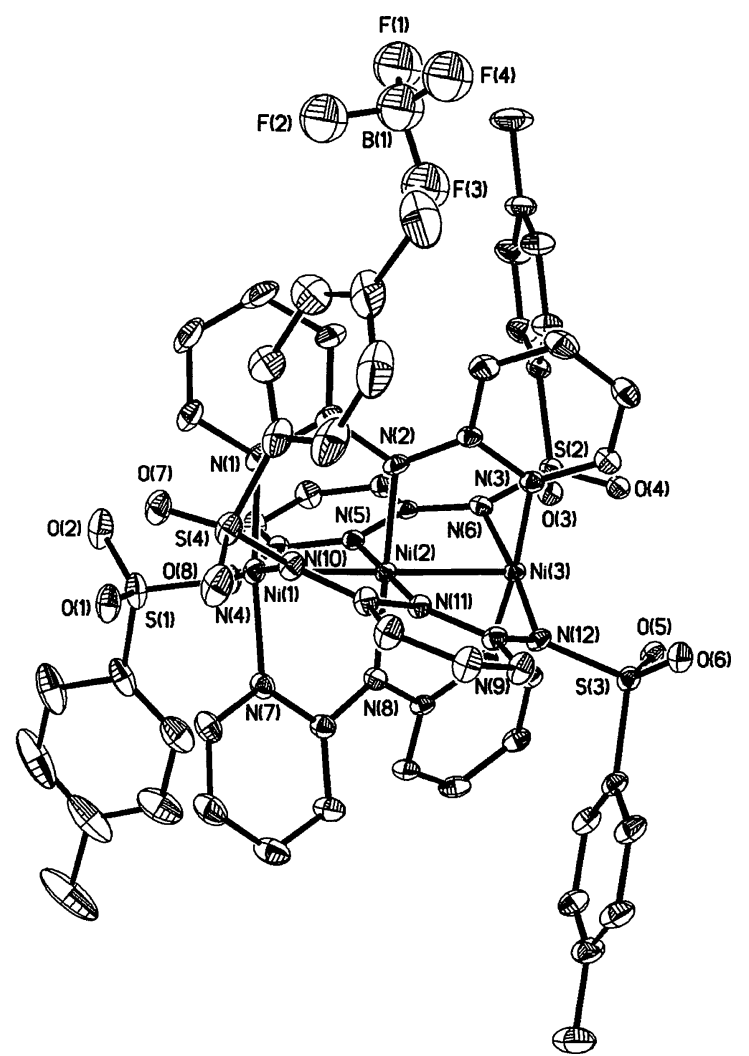

Fig. 5 Crystal structure of 5. Thermal ellipsoids are drawn at the 30\% probability level. Hydrogen atoms are omitted for clarity.

\section{Electrochemistry}

Cyclic voltammograms of compounds $\mathbf{1 - 4}$ in $\mathrm{CH}_{2} \mathrm{Cl}_{2}$ containing $0.1 \mathrm{M}$ TBAP are shown in Fig. 7. In the case of compounds $\mathbf{1}$ and 2 , three redox couples were observed at $+0.85,-0.58$, and $-1.12 \mathrm{~V}$ for $\mathbf{1}$ and $+0.86,-0.51$, and $-1.09 \mathrm{~V}$ for $\mathbf{2}$. For compounds $\mathbf{3}$ and 4, all the electrochemical reactions are irreversible.

To improve understanding of the electrochemical properties of compound 1, spectroelectrochemical studies were carried out. Fig. 8 shows the spectral changes for compound $\mathbf{1}$ at applied potentials from +0.42 to $+1.130 \mathrm{~V}$ in $\mathrm{CH}_{2} \mathrm{Cl}_{2}$ containing $0.1 \mathrm{M}$

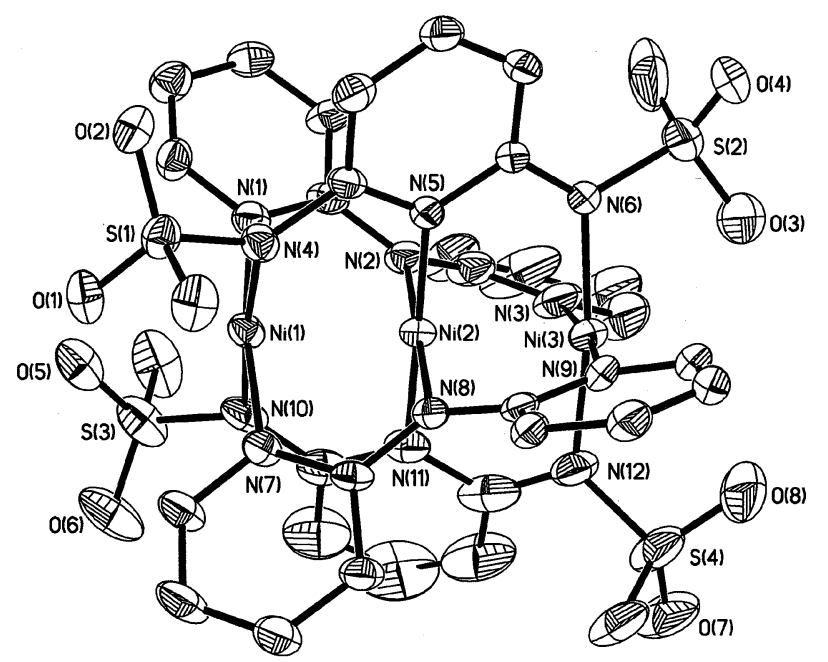

Fig. 6 Crystal structure of 6. Thermal ellipsoids are drawn at the $30 \%$ probability level. Hydrogen atoms are omitted for clarity.

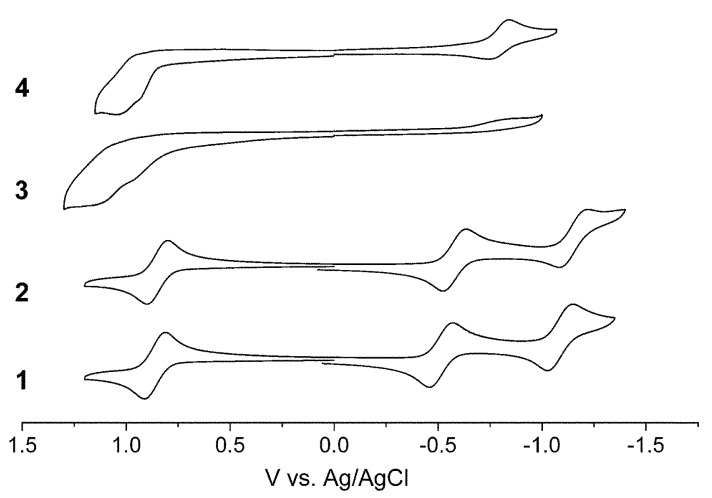

Fig. 7 The cyclic voltammograms of linear trinuclear string complexes 1-4 in $\mathrm{CH}_{2} \mathrm{Cl}_{2}$ containing $0.1 \mathrm{M}$ TBAP.

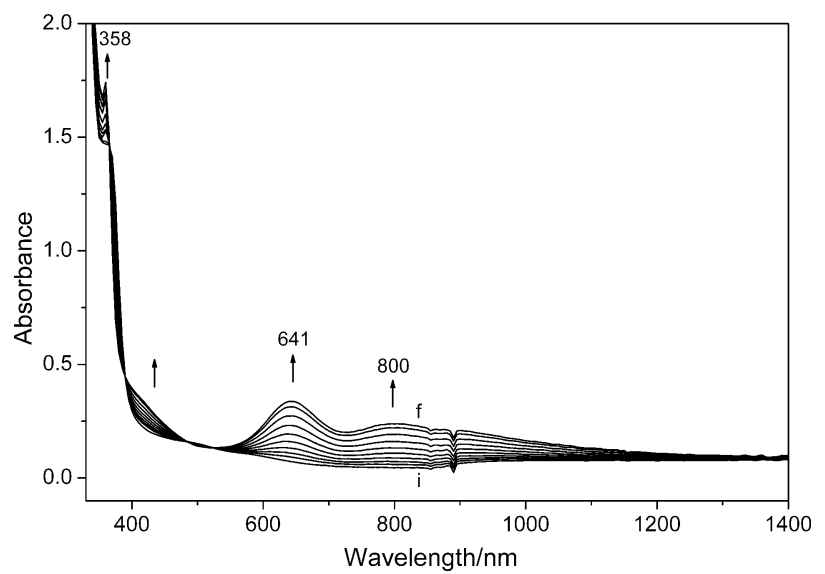

Fig. 8 UV-Vis spectral changes for the first oxidation of compound 1 in $\mathrm{CH}_{2} \mathrm{Cl}_{2}$ with $0.1 \mathrm{M}$ TBAP at various applied potentials: $+0.42,+0.78$, $+0.81,+0.84,+0.87,+0.90,+0.93,+0.96,+1.11$, and $+1.13 \mathrm{~V} ; i=+0.42 \mathrm{~V}$ and $f=+1.13 \mathrm{~V}$.

TBAP. The peaks at 358, 430, 641 and $800 \mathrm{~nm}$ increase during the oxidation of compound $\mathbf{1}$. The resulting spectrum is similar to that of the one-electron oxidized product of $\mathbf{1}$, obtained by a chemical 
method, suggesting that the oxidation is a metal-centered reaction. Based on the spectral changes observed for $\mathbf{1}$ at various applied potentials, the number of electrons transferred was calculated to be one. ${ }^{20}$

\section{Magnetic properties}

Variable temperature magnetic susceptibility measurements were performed on crushed single crystals of $\mathbf{1}$ and $\mathbf{5}$ at $10000 \mathrm{G}$ from 300 to $5 \mathrm{~K}$. The $\chi_{\mathrm{M}} T$ values of $\sim 0.098$ and $0.429 \mathrm{emu} \mathrm{K} \mathrm{mol}{ }^{-1}$ at $300 \mathrm{~K}$ are in agreement with the expected the values of 0 and 0.375 emu $\mathrm{K} \mathrm{mol}^{-1}$ for nickel ions with $S=0$ and $S=1 / 2$, respectively. For compounds 2 and 4, the $\chi_{\mathrm{M}} T$ values of $\sim 1.142$ and $1.214 \mathrm{emu}$ $\mathrm{K} \mathrm{mol}^{-1}$ at $300 \mathrm{~K}$ are in agreement with the expected value of $1 \mathrm{emu}$ $\mathrm{K} \mathrm{mol}^{-1}$ for one five-coordinate nickel ion (high spin state of $S=1$ ). The $\chi_{\mathrm{M}} T$ value of $\sim 0.096 \mathrm{emu} \mathrm{K} \mathrm{mol}^{-1}$ at $300 \mathrm{~K}$ for 6 is consistent with a system with a spin state of $S=0$. The molar magnetic susceptibilities $\chi_{\mathrm{M}}$ and $\chi_{\mathrm{M}} T$ with respect to temperature (Fig. 9) for compound 3 are similar to those for $\left[\mathrm{Ni}_{3}(\mathrm{dpa})_{4} \mathrm{Cl}_{2}\right]$. The theoretical simulation curves (solid line) agree well with the measurements. The electronic configurations derived from structural analyses are in good agreement with the experimental magnetic measurements, with the central $\mathrm{Ni}(\mathrm{II})$ ion being in a low spin $(S=0)$ state and two terminal Ni(II) ions being in high spin $(S=1)$ states. Based on an isotropic interaction between two $S=1$ centers with the spin Hamiltonian $H=-2 J \hat{\boldsymbol{S}}_{1} \cdot \hat{\boldsymbol{S}}_{6}$, the simulated curve of $\chi_{\mathrm{M}} T$ was fitted using the following equation: ${ }^{11}$

$$
\begin{aligned}
x_{\mathrm{M}}= & (1-P) C^{\prime}\left(2 e^{2 x}+10 e^{6 x}\right) /\left(1+3 e^{2 x}+5 e^{6 x}\right) \\
& +P\left(2 N g^{2} \beta^{2} / 3 k T\right)+N a
\end{aligned}
$$

where $C^{\prime}=N g^{2} \beta^{2} / k(T-\theta), x=J_{13} / K T, N=6.022 \times 10^{23}, g$ is the $g$-factor, $\beta$ is the Bohr magneton, $k$ (Boltzmann) $=0.695 \mathrm{~cm}^{-1} \mathrm{~K}^{-1}$, $T$ is the absolute temperature in $\mathrm{K}, J_{13}$ is the coupling constant between $\mathrm{Ni}(1)$ and $\mathrm{Ni}(3), \chi$ is the Weiss temperature (or Weiss constant), $N \alpha$ is the temperature-independent paramagnetism (TIP), and $P$ is the relative content (fraction) for paramagnetic impurity where spin state $S=1$ is assumed.

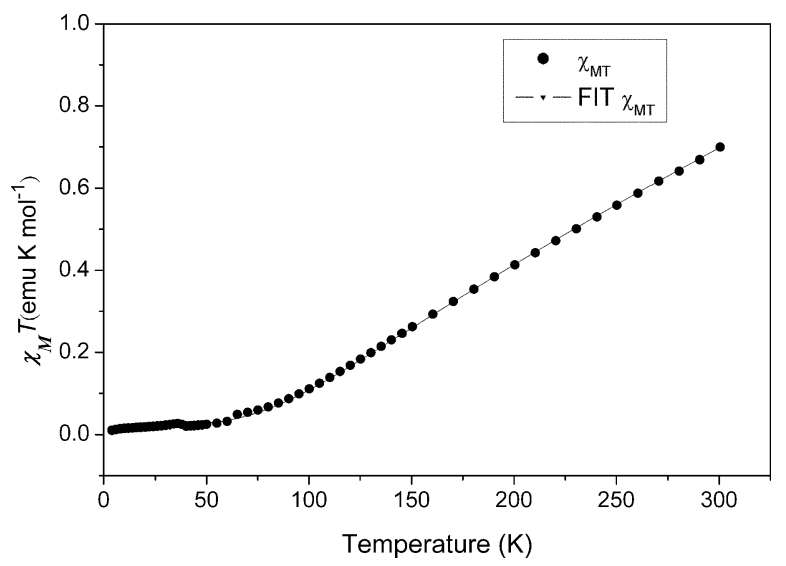

Fig. 9 Temperature dependent $\chi_{\mathrm{M}} T$ (๑) for compound 3. The solid line represents the results of theoretical simulation.

$J_{13}$ values were obtained by minimizing the function $R=\Sigma$ $\left(X_{\mathrm{M}}{ }^{\text {calcd }}-X_{\mathrm{M}}{ }^{\text {obs }}\right)^{2} /\left(\Sigma X_{\mathrm{M}}{ }^{\text {obs }}\right)^{2}$. The best fitting parameters obtained were $J_{13}=-125 \mathrm{~cm}^{-1}, g=2.0$, TIP $=1.58 \times 10^{-4}, P=0.017$, and $\theta=-7.86 \times 10^{-8}$ for compound 3 with a correlation coefficient of 0.9998 . The negative $J_{13}$ value of $\mathbf{3}$ reveals an antiferromagnetic interaction between the two terminal high-spin $\mathrm{Ni}(\mathrm{II})$ ions by the intra- $\mathrm{Ni}(1) \cdots \mathrm{Ni}(3)$ interaction through the $\mathrm{Ni}(2)$ ions with the $\mathrm{Ni}(1) \cdots \mathrm{Ni}(3)$ distance of $4.807 \AA$.

\section{Conclusions}

This work describes the preparation, crystal structures, and properties of linear trinuclear nickel metal string complexes with mixed ligands, including both neutral and one-electron oxidized compounds. The symmetrical and unsymmetrical structures of these complexes with different mixed ligands were confirmed by $\mathrm{X}$-ray crystal structure analysis.

Due to these axial interactions, compounds 1-4and compound $\mathbf{6}$ show dramatic differences in their molecular structures and magnetic properties. In conclusion, structural and magnetic evidence shows that a $\mathrm{Ni}$ atom lacking an axial coordination should be in a low spin $(S=0)$ ground state. However, a Ni atom exhibited axial coordination is in a high spin $(S=1)$ ground state. For example, the spin state of each $\mathrm{Ni}$ atom in compound $\mathbf{1 ,} \mathbf{2}$ and $\mathbf{3}$ are $(0,0,0)$, $(1,0,0)$, and $(1,0,1)$, respectively. In addition, the neutral and one-electron oxidized molecules $\mathbf{1}$ and $\mathbf{5}$ exhibit spin states of $S=$ 0 and $1 / 2$, respectively.

\section{Experimental}

\section{General}

All reagents and solvents were obtained from commercial sources and were used without further purification, unless otherwise noted. $\mathrm{CH}_{2} \mathrm{Cl}_{2}$, used for the electrochemistry, was dried over $\mathrm{CaH}_{2}$ and freshly distilled prior to use. Tetra- $n$-butylammonium perchlorate (TBAP) was recrystallized twice from ethyl acetate and dried under vacuum. The dpaH, ${ }^{5-7}$ peptea $H_{4},{ }^{16} \mathrm{LptsH}_{2}{ }^{21}$ and $\mathrm{LmsH}_{2}{ }^{21}$ ligands were synthesized according to the literature.

\section{Physical measurements}

Absorption spectra were recorded on Hewlett Packard model 8453 or JASCO V-570 spectrophotometers. IR spectra were obtained using a Nicolet Fourier-Transform IR spectrometer in the range of $500-4000 \mathrm{~cm}^{-1}$. FAB-MS mass spectra were obtained with a JEOL HX-110 HF double focusing spectrometer operating in the positive ion detection mode. Molar magnetic susceptibility was recorded in the range of $5-300 \mathrm{~K}$ on a SQUID system with a $10000 \mathrm{Ga}$ external magnetic field. Electrochemical measurements were performed with a three electrode potentiostat (CHI 750) in a $\mathrm{CH}_{2} \mathrm{Cl}_{2}$ solution deoxygenated by purging with purified nitrogen gas. Cyclic voltammetry was conducted with the use of a homemade three electrode cell equipped with a BAS glassy carbon $\left(0.07 \mathrm{~cm}^{2}\right)$ or platinum $\left(0.02 \mathrm{~cm}^{2}\right)$ disc as the working electrode, a platinum wire as the auxiliary electrode, and a homemade $\mathrm{Ag} / \mathrm{AgCl}$ (sat'd) reference electrode. The reference electrode was separated from the bulk solution by a double junction filled with electrolyte solution. Potentials were reported vs. $\mathrm{Ag} / \mathrm{AgCl}$ (sat'd) and referenced to the ferrocene/ferrocenium $\left(\mathrm{Fc} / \mathrm{Fc}^{+}\right)$couple which occurs at $E_{1 / 2}=+0.54 \mathrm{~V} v$ s. $\mathrm{Ag} / \mathrm{AgCl}$ (sat'd). The working electrode was polished with $0.03 \mu \mathrm{m}$ aluminium on Buehler felt pads and was treated with ultrasound for $1 \mathrm{~min}$ prior to each experiment. The reproducibility of individual potential values 
was within $\pm 5 \mathrm{mV}$. The spectroelectrochemical experiments were accomplished with the use of a $1 \mathrm{~mm}$ cuvette, a 100 mesh platinum gauze as working electrode, a platinum wire as auxiliary electrode, and an $\mathrm{Ag} / \mathrm{AgCl}$ (sat'd) reference electrode.

\section{Syntheses}

Preparation of $N, N^{\prime}$-biacetylpyridyldiamine $\left(\mathrm{LAcH}_{2}\right)$. Under a nitrogen atmosphere, 2,6-diaminopyridine ( $5 \mathrm{~g}, 0.046 \mathrm{~mol})$ was added to a solution of acetic anhydride $(10.4 \mathrm{~mL}, 0.055 \mathrm{~mol})$ in $1,4-$ dioxane $(100 \mathrm{~mL})$. The reaction mixture was heated at reflux for $24 \mathrm{~h}$. After cooling to room temperature, the solvent was removed using a rotary evaporator. Unreacted 2,6-diaminopyridine and acetic anhydride were rinsed away with water. The resulting dark material was purified by chromatography using silica gel and dichloromethane-acetone $(1: 1)$ as the eluent to afford $\mathrm{LAcH}_{2}$ as a white powder. Yield $6.31 \mathrm{~g}(72 \%) .{ }^{1} \mathrm{H}$ NMR $\left(400 \mathrm{MHz}, \mathrm{d}^{6}-\right.$ dmso, $\delta$ ): 10.04 (s, 2H), $7.69(\mathrm{~m}, 3 \mathrm{H}), 2.09$ (s, 6H). Anal. Calcd for $\mathrm{C}_{9} \mathrm{H}_{11} \mathrm{~N}_{3} \mathrm{O}_{2}$ : C, 55.95; H, 5.74; N, 21.75; found C, 55.37; H, 5.81; N, $21.34 \%$.

Preparation of $\left[\mathrm{Ni}_{3}(\mathbf{L p t s})_{2}(\mathbf{d p a})_{2}\right] \quad$ (1). $\mathrm{LptsH}_{2} \quad(0.417 \quad \mathrm{~g}$, $1.0 \mathrm{mmol})$, dpaH $(0.171 \mathrm{~g}, 1.0 \mathrm{mmol}), \mathrm{Ni}(\mathrm{OAc})_{2} \cdot 4 \mathrm{H}_{2} \mathrm{O}(0.375 \mathrm{~g}$, $1.5 \mathrm{mmol})$ and naphthalene $(20 \mathrm{~g})$ were placed in an Erlenmeyer flask. The resulting solution was stirred at $220{ }^{\circ} \mathrm{C}$ for $3 \mathrm{~h}$. After cooling the mixture to $80^{\circ} \mathrm{C}$, hexane $(100 \mathrm{~mL})$ was added and the resulting precipitate was filtered out. The solid was extracted with $\mathrm{CH}_{2} \mathrm{Cl}_{2}$ and recrystallized from $\mathrm{CH}_{2} \mathrm{Cl}_{2}$ and methanol to remove the mononuclear complex. The solid was filtered and then washed with $\mathrm{THF}$ to remove the by-product $\mathrm{Ni}_{3}(\mathrm{dpa})_{4}(\mathrm{OAc})_{2}$. Crystals were obtained by crystallization via slow diffusion of diethyl ether vapor into the $\mathrm{CH}_{2} \mathrm{Cl}_{2}$. Yield $0.32 \mathrm{~g}(48 \%)$. IR $\left(\mathrm{KBr}, \mathrm{cm}^{-1}\right)$ : 1140, $1109(\mathrm{~S}=\mathrm{O}), 1583,1467,1431$ (py); UV/Vis $\left(\mathrm{CH}_{2} \mathrm{Cl}_{2}\right)$ $\lambda_{\max } / \mathrm{nm}\left(\varepsilon / \mathrm{dm}^{3} \mathrm{~mol}^{-1} \mathrm{~cm}^{-1}\right): 272$ (55 600), 320 (73 300),366 (36 600); MS(FAB) $m / z: 1346\left(\left[\mathrm{Ni}_{3}(\mathrm{Lpts})_{2}(\mathrm{dpa})_{2}\right]^{+}\right)$; Anal. calcd for $\mathrm{C}_{58} \mathrm{H}_{50} \mathrm{~N}_{12} \mathrm{Ni}_{3} \mathrm{O}_{8} \mathrm{~S}_{4}$ : C, 51.70; H, 3.74; N, 12.47; found C, 51.29; $\mathrm{H}$, $3.83 ; \mathrm{N}, 12.25 \%$.

Preparation of $\left[\mathrm{Ni}_{3}(\mathbf{L m s})_{2}(\mathbf{d p a})_{\mathbf{2}}\left(\mathbf{H}_{\mathbf{2}} \mathrm{O}\right)\right]$ (2). $\mathrm{LmsH}_{2}(0.265 \mathrm{~g}$, $1.0 \mathrm{mmol})$, dpaH $(0.171 \mathrm{~g}, 1.0 \mathrm{mmol}), \mathrm{Ni}(\mathrm{OAc})_{2} \cdot 4 \mathrm{H}_{2} \mathrm{O}(0.375 \mathrm{~g}$, $1.5 \mathrm{mmol})$ and naphthalene $(20 \mathrm{~g})$ were placed in an Erlenmeyer flask. The resulting solution was stirred at $220{ }^{\circ} \mathrm{C}$ for $3 \mathrm{~h}$. After cooling the mixture to $80^{\circ} \mathrm{C}$, hexane $(100 \mathrm{~mL})$ was added and the resulting precipitate was filtered out. The solid was extracted with $\mathrm{CH}_{2} \mathrm{Cl}_{2}$ and recrystallized from $\mathrm{CH}_{2} \mathrm{Cl}_{2}$ and hexane. The solid was filtered and then washed with THF to remove the by-product $\left[\mathrm{Ni}_{3}(\mathrm{dpa})_{4}(\mathrm{OAc})_{2}\right]$. Crystals were obtained by crystallization via slow diffusion of diethyl ether vapor into the $\mathrm{CH}_{2} \mathrm{Cl}_{2}$. Yield $0.28 \mathrm{~g}$ (54\%). IR ( $\left.\mathrm{KBr}, \mathrm{cm}^{-1}\right): 1128,1081(\mathrm{~S}=\mathrm{O}), 1604,1574,1470,1430$ (py); UV/Vis $\left(\mathrm{CH}_{2} \mathrm{Cl}_{2}\right) \lambda_{\max } / \mathrm{nm}\left(\varepsilon / \mathrm{dm}^{3} \mathrm{~mol}^{-1} \mathrm{~cm}^{-1}\right): 316(44800)$, 366 (21 300); MS (FAB) $m / z: 1042\left(\left[\mathrm{Ni}_{3}\left(\mathrm{Lms}_{2}-(\mathrm{dpa})_{2}\right]^{+}\right)\right.$; Anal. calcd for $\mathrm{C}_{34} \mathrm{H}_{34} \mathrm{~N}_{12} \mathrm{Ni}_{3} \mathrm{O}_{8} \mathrm{~S}_{4}$ : C, 39.15; H, 3.29; N, 16.11; found $\mathrm{C}$, $39.01 ; \mathrm{H}, 3.38 ; \mathrm{N}, 15.94 \%$.

Preparation of $\left[\mathrm{Ni}_{3}(\mathbf{L A c})_{2}(\mathbf{d p a})_{2}\right] \quad$ (3). $\mathrm{LAcH}_{2} \quad(0.193 \mathrm{~g}$, $1.0 \mathrm{mmol})$, dpaH (0.171 g, $1.0 \mathrm{mmol}), \mathrm{Ni}(\mathrm{OAc})_{2} \cdot 4 \mathrm{H}_{2} \mathrm{O}(0.375 \mathrm{~g}$, $1.5 \mathrm{mmol})$ and naphthalene $(20 \mathrm{~g})$ were placed in an Erlenmeyer flask. The resulting solution was stirred at $220{ }^{\circ} \mathrm{C}$ for $3 \mathrm{~h}$. After cooling the mixture to $80{ }^{\circ} \mathrm{C}$, hexane $(100 \mathrm{~mL})$ was added and the resulting precipitate was filtered out. The solid was extracted with $\mathrm{CH}_{2} \mathrm{Cl}_{2}$ and recrystallized from $\mathrm{CH}_{2} \mathrm{Cl}_{2}-$ methanol (1:4) to remove the mononuclear complex. Crystals were obtained by crystallization via slow diffusion of diethyl ether vapor into benzene. Yield $0.21 \mathrm{~g}(47 \%)$. IR $\left(\mathrm{KBr}, \mathrm{cm}^{-1}\right): 1686(\mathrm{C}=\mathrm{O}), 1601$, 1530, 1434 (py); UV/Vis $\left(\mathrm{CH}_{2} \mathrm{Cl}_{2}\right) \lambda_{\max } / \mathrm{nm}\left(\varepsilon / \mathrm{dm}^{3} \mathrm{~mol}^{-1} \mathrm{~cm}^{-1}\right)$ : 290 (37 800), 322 (36 100), 366 (14 400); MS(FAB) m/ $z: 897$ $\left(\left[\mathrm{Ni}_{3}(\mathrm{LAc})_{2}(\mathrm{dpa})_{2}\right]^{+}\right)$; Anal. Calcd for $\mathrm{C}_{38} \mathrm{H}_{34} \mathrm{~N}_{12} \mathrm{Ni}_{3} \mathrm{O}_{4}$ : C, 50.78; $\mathrm{H}, 3.81$; N, 18.70; found C, 49.89; H, 3.93; N, $18.43 \%$.

Preparation of $\left[\mathrm{Ni}_{3}(\mathbf{L p t s})_{2}\left(\right.\right.$ pepteaH $\left.\left.H_{2}\right)\right]$ (4). $\mathrm{LptsH}_{2}(0.417 \mathrm{~g}$, $1.0 \mathrm{mmol})$, peptea $\mathrm{H}_{4}(0.447 \mathrm{~g}, 1.0 \mathrm{mmol}), \mathrm{Ni}(\mathrm{OAc})_{2} \cdot 4 \mathrm{H}_{2} \mathrm{O}(0.375 \mathrm{~g}$, $1.5 \mathrm{mmol})$ and naphthalene $(20 \mathrm{~g})$ were placed in an Erlenmeyer flask. The resulting solution was stirred at $220{ }^{\circ} \mathrm{C}$ for $3 \mathrm{~h}$. After cooling the mixture to $80{ }^{\circ} \mathrm{C}$, hexane $(100 \mathrm{~mL})$ was added and the resulting precipitate was collected by filtration. The solid was washed with $\mathrm{CH}_{2} \mathrm{Cl}_{2}$ and methanol to remove the residual ligands and mononuclear complex. Crystals were obtained by crystallization via slow diffusion of diethyl ether vapor into DMF. Yield $0.23 \mathrm{~g}(32 \%)$. IR $\left(\mathrm{KBr}, \mathrm{cm}^{-1}\right)$ : 1138 , $1085(\mathrm{~S}=\mathrm{O}), 1577,1447,1430$ (py); UV/Vis (DMF) $\lambda_{\max } / \mathrm{nm}$ $\left(\varepsilon / \mathrm{dm}^{3} \mathrm{~mol}^{-1} \mathrm{~cm}^{-1}\right): 340$ (49 300), 374 (26 300); MS (FAB) $\mathrm{m} / z$ : $\left.1451\left(\left[\mathrm{Ni}_{3}(\text { Lpts) })_{2} \text { (pepteaH }\right]_{2}\right)\right]^{+}$, Anal. Calcd for $\mathrm{C}_{63} \mathrm{H}_{53} \mathrm{~N}_{15} \mathrm{Ni}_{3} \mathrm{O}_{4}$ : C, 52.09; H, 3.68; N, 14.46; found C, 51.29; H, 3.81; N, 14.18\%.

Preparation of $\left[\mathrm{Ni}_{3}(\mathbf{L p t s})_{2}(\mathbf{d p a})_{2}\right]\left(\mathbf{B F}_{4}\right)(5)$. To a solution of $\left[\mathrm{Ni}_{3}(\mathrm{Lpts})_{2}(\mathrm{dpa})_{2}\right](134 \mathrm{mg}, 0.10 \mathrm{mmol})$ in $\mathrm{CH}_{2} \mathrm{Cl}_{2}(50 \mathrm{~mL})$ was added $\mathrm{NOBF}_{4}(23 \mathrm{mg}, 0.2 \mathrm{mmol})$ in $\mathrm{CH}_{3} \mathrm{OH}(1 \mathrm{~mL})$. The resulting mixture was stirred for $1 \mathrm{~h}$ and the precipitate removed by filtration. The solvent was removed under reduced pressure. Crystals were obtained by crystallization via slow diffusion of diethyl ether vapor into the solution. Yield $0.031 \mathrm{~g}(23 \%)$. IR $\left(\mathrm{KBr}, \mathrm{cm}^{-1}\right): 1138$, $1107(\mathrm{~S}=\mathrm{O}), 1581,1467,1428$ (py); UV/Vis $\left(\mathrm{CH}_{2} \mathrm{Cl}_{2}\right) \lambda_{\max } / \mathrm{nm}$ ( $\left.\varepsilon / \mathrm{dm}^{3} \mathrm{~mol}^{-1} \mathrm{~cm}^{-1}\right): 320$ (48 400), 366 (23 200), 420 (60 400), 640 (2580); MS (FAB) $m / z: 1346\left(\left[\mathrm{Ni}_{3}(\mathrm{Lpts})_{2}(\mathrm{dpa})_{2}\right]^{+}\right)$; Anal. Calcd for $\mathrm{C}_{58} \mathrm{H}_{50} \mathrm{BF}_{4} \mathrm{~N}_{12}-\mathrm{Ni}_{3} \mathrm{O}_{8} \mathrm{~S}_{4}: \mathrm{C}, 48.57 ; \mathrm{H}, 3.51 ; \mathrm{N}, 11.72$; found $\mathrm{C}$, $48.15 ; \mathrm{H}, 3.54 ; \mathrm{N}, 11.65 \%$.

\section{Preparation of $\left[\mathrm{Ni}_{3}(\mathrm{Lms})_{2}(\mathrm{dpa})_{2}\right] \quad$ (6). Crystals of} $\left[\mathrm{Ni}_{3}(\mathrm{Lms})_{2}(\mathrm{dpa})_{2}\left(\mathrm{H}_{2} \mathrm{O}\right)\right](104 \mathrm{mg}, 0.10 \mathrm{mmol})$ were left under vacuum at $120^{\circ} \mathrm{C}$ for $48 \mathrm{~h}$. The color of the crystals changed from dark black to brown. Crystals were obtained by crystallization via slow diffusion of diethyl ether vapor into $\mathrm{CH}_{2} \mathrm{Cl}_{2}$. Yield $0.09 \mathrm{~g}$ (98\%). IR (KBr, cm $\left.{ }^{-1}\right)$ : 1128, $1081(\mathrm{~S}=\mathrm{O}), 1604,1574,1470$, 1430 (py); UV/Vis $\left(\mathrm{CH}_{2} \mathrm{Cl}_{2}\right) \lambda_{\max } / \mathrm{nm}\left(\varepsilon / \mathrm{dm}^{3} \mathrm{~mol}^{-1} \mathrm{~cm}^{-1}\right): 316$ (44 800), 366 (21 300); MS (FAB) $m / z: 1042\left(\left[\mathrm{Ni}_{3}(\mathrm{Lms})_{2}-(\mathrm{dpa})_{2}\right]^{+}\right)$; Anal. Calcd for $\mathrm{C}_{38} \mathrm{H}_{44} \mathrm{~N}_{12} \mathrm{Ni}_{3} \mathrm{O}_{9} \mathrm{~S}_{4}: \mathrm{C}, 40.85 ; \mathrm{H}, 3.97 ; \mathrm{N}, 15.05 .11$; found $\mathrm{C}, 40.31 ; \mathrm{H}, 3.88 ; \mathrm{N}, 15.94 \%$.

\section{X-Ray crystallographic determinations}

Crystallographic information for $\mathbf{1 - 6}$ is summarized in Tables 1 and 2 . The chosen crystals were mounted on a glass fiber. X-Ray diffraction data for $\mathbf{1}, \mathbf{3}, \mathbf{4}$ and $\mathbf{6}$ were collected at $150 \mathrm{~K}$ on a Nonius Kappa CCD diffractometer installed with monochromatized Mo K $\alpha$ radiation, $\lambda=0.71073 \AA$. Complexes $\mathbf{2}$, and $\mathbf{5}$ were collected at $150 \mathrm{~K}$ on a Bruker Smart ApexCCD diffractometer installed with monochromatized Mo K $\alpha$ radiation, $\lambda=0.71073 \AA$, using SAINT (Version 6.22, Bruker) for cell constants from global refinement. Cell parameters were retrieved and refined using DENZOSMN software on all observed reflections. ${ }^{22}$ Data reduction was performed with the DENZOSMN software. ${ }^{22}$ An empirical absorption based on the symmetry-equivalent reflection 
and absorption corrections was applied with the SORTAV program. ${ }^{23}$ All the structures were solved by using SHELXS-97 software ${ }^{24}$ and refined with SHELXL-9725 by full-matrix least squares on $F^{2}$ values. Hydrogen atoms were fixed at calculated positions and refined using a riding mode.

CCDC reference numbers 618763-618768. For crystallographic data in CIF or other electronic format see DOI: 10.1039/b612123c

\section{Acknowledgements}

The authors acknowledge the National Science Council and Ministry of Education of Taiwan for financial support.

\section{References}

1 (a) F. Mota, J. J. Novoa, J. Losada, S. Alvarez, R. Hoffmann and J. Silverstre, J. Am. Chem. Soc., 1993, 115, 6216; (b) J. Losada, S. Alvarez, J. J. Novoa, F. Mota, R. Hoffmann and J. Silverstre, J. Am. Chem. Soc., 1990, 112, 8998.

2 F. A. Cotton, C. A. Murillo and R. A. Walton, Multiple Bonds Between Atoms, Springer-Verlag, New York, 3rd edn, 2005.

3 F. A. Cotton and G. Wilkinson, Advanced Inorganic Chemistry, Wiley, New York, 5th edn, 1988, ch. 23.

4 Metal-Metal Bonds and Clusters in Chemistry and Catalysis, ed. J. P. Fackler, Plenum, New York, 1989.

5 S. Aduldecha and B. Hathaway, J. Chem. Soc., Dalton Trans., 1991, 993.

6 (a) G. J. Pyrka, M. El-Mekki and A. A. Pinkerton, J. Chem. Soc., Chem. Commun., 1991, 84; (b) L. P. Wu, P. Field, T. Morrissey, C. Murphy, P. Nagle, B. Hathaway, C. Simmons and P. Thornton, J. Chem. Soc., Dalton Trans., 1990, 3835.

7 E. C. Yang, M. C. Cheng, M. S. Tsai and S. M. Peng, J. Chem. Soc., Chem. Commun., 1994, 2377.
8 (a) F. A. Cotton, L. M. Daniels, C. A. Murillo and I. Pascual, J. Am. Chem. Soc., 1997, 119, 10223; (b) F. A. Cotton, L. M. Daniels, C. A. Murillo and X. Wang, Chem. Commun., 1998, 39.

9 J. T. Sheu, C. C. Lin, I. Chao, C. C. Wang and S. M. Peng, Chem. Commun., 1996, 315.

10 (a) F. A. Cotton, L. M. Daniels and G. T. Jordan IV, Chem. Commun., 1997, 421; (b) F. A. Cotton, L. M. Daniels, G. T. Jordan IV and C. A. Murillo, J. Am. Chem. Soc., 1997, 119, 10377.

11 S. J. Shieh, C. C. Chou, G. H. Lee, C. C. Wang and S. M. Peng, Angew. Chem., Int. Ed. Engl., 1997, 36, 56.

12 C. C. Wang, W. C. Lo, C. C. Chou, G. H. Lee, J. M. Chen and S. M. Peng, Inorg. Chem., 1998, 37, 4059.

13 H. C. Chang, J. T. Li, C. C. Wang, T. W. Lin, H. C. Lee, G. H. Lee and S. M. Peng, Eur. J. Inorg. Chem., 1999, 1243.

14 (a) S. Y. Lai, T. W. Lin, Y. H. Chen, C. C. Wang, G. H. Lee, M. H. Yang, M. K. Leung and S. M. Peng, J. Am. Chem. Soc., 1999, 121, 250; (b) S. Y. Lai, C. C. Wang, Y. H. Chen, C. C. Lee, Y. H. Liu and S. M. Peng, J. Chin. Chem. Soc., 1999, 46, 477.

15 Y. H. Chen, C. C. Lee, C. C. Wang, G. H. Lee, S. Y. Lai, F. Y. Li, C. Y. Mou and S. M. Peng, Chem. Commun., 1999, 1667.

16 S. M. Peng, C. C. Wang, Y. L. Jang, Y. H. Chen, F. Y. Li, C. Y. Mou and M. K. Leung, J. Magn. Magn. Mater., 2000, 209, 80.

17 S. Y. Lai, T. W. Lin, Y. H. Chen, C. C. Wang, G. H. Lee, M. H. Yang, M. K. Leung and S. M. Peng, J. Am. Chem. Soc., 1999, 121, 250.

18 F. A. Cotton, L. M. Daniel, C. A. Murillo and X. Wang, Inorg. Chem., 2001, 40, 2778.

19 X. López, M. Bénard and M.-M. Rohmer, submitted to Inorg. Chem.

20 D. F. Rohrbach, E. Deutsch, W. R. Heineman and R. F. Pasternack, Inorg. Chem., 1977, 16, 2650.

21 M. Tsai and S. M. Peng, Bull. Inst. Chem. Acad. Sin., 1995, 42, 63.

22 Z. Otwinowski and W. Minor, in Methods in Enzymology: Macromolecular Crystallography, Part A, ed. C. W. Carter Jr and R. M. Sweet, Academic Press, San Diego, 1997, vol. 276.

23 R. H. Blessing, Acta Crystallogr., Sect. A, 1995, 33.

24 G. M. Sheldrick, Acta Crystallogr., Sect. A, 1990, 467.

25 G. M. Sheldrick, SHELXL-97, Program for the Refinement of Crystal Structures, University of Göttingen, Germany, 1997. 